NBER WORKING PAPER SERIES

DEMYSTIFYING THE DESTINATION-BASED CASH-FLOW TAX

\author{
Alan J. Auerbach \\ Working Paper 23881 \\ http://www.nber.org/papers/w23881 \\ NATIONAL BUREAU OF ECONOMIC RESEARCH
1050 Massachusetts Avenue
Cambridge, MA 02138
September 2017
}

This paper was originally prepared for the Brookings Panel on Economic Activity and presented at its Fall, 2017, conference. I am grateful to Dhammika Dharmapala, Bill Gale, Mick Keen, Drew Lyon, Peter Merrill, Jim Stock, John Vella, Alan Viard, and conference participants for comments on earlier drafts. The views expressed herein are those of the author and do not necessarily reflect the views of the National Bureau of Economic Research.

The author has disclosed a financial relationship of potential relevance for this research. Further information is available online at http://www.nber.org/papers/w23881.ack

NBER working papers are circulated for discussion and comment purposes. They have not been peer-reviewed or been subject to the review by the NBER Board of Directors that accompanies official NBER publications.

(C) 2017 by Alan J. Auerbach. All rights reserved. Short sections of text, not to exceed two paragraphs, may be quoted without explicit permission provided that full credit, including (C) notice, is given to the source. 
Demystifying the Destination-Based Cash-Flow Tax

Alan J. Auerbach

NBER Working Paper No. 23881

September 2017

JEL No. F23,H25

\title{
ABSTRACT
}

This paper describes the Destination-Based Cash-Flow Tax (DBCFT), as proposed in 2016 by Republicans in the US House of Representatives, and its potential economic effects. As a new approach and a major departure from the existing business tax system, the DBCFT and its motivation have been poorly understood by many in government, the business community, and the economics profession.

\author{
Alan J. Auerbach \\ Department of Economics \\ 530 Evans Hall, \#3880 \\ University of California, Berkeley \\ Berkeley, CA 94720-3880 \\ and NBER \\ auerbach@econ.berkeley.edu
}




\title{
Demystifying the Destination-Based Cash-Flow Tax
}

\author{
Alan J. Auerbach* \\ University of California, Berkeley \\ Revised, September 22, 2017
}

\begin{abstract}
This paper describes the Destination-Based Cash-Flow Tax (DBCFT), as proposed in 2016 by Republicans in the US House of Representatives, and its potential economic effects. As a new approach and a major departure from the existing business tax system, the DBCFT and its motivation have been poorly understood by many in government, the business community, and the economics profession.
\end{abstract}

Since the introduction of the House Republican tax plan in June, $2016^{1}$ (sometimes referred to as the House Blueprint), and especially after the November election that brought unified Republican control of the federal government, a key provision of the tax plan, for destinationbased cash-flow taxation (DBCFT) of businesses, has received considerable attention. While not new to the public finance and tax policy literature, it was a novel Congressional proposal, and its consideration generated a significant amount of lobbying activity, editorial commentary, and serious attention from tax specialists and, eventually, the broader community of economists, many of whom had previously been unfamiliar with the approach. But the approach, its potential economic effects, and its rationale remain poorly understood.

\section{What is the DBCFT?}

One may think of the DBCFT as modifying two elements of the existing structure of US business taxation, applying to (1) domestic US activities and (2) international activities. With respect to the former, the DBCFT would replace the income tax with a cash-flow tax, substituting depreciation allowances with immediate investment expensing and eliminating interest deduction for nonfinancial companies. On the international side, the DBCFT would replace the current "worldwide" tax system, under which US activities of US and foreign businesses and foreign activities of US businesses are subject to US taxation, with a territorial system that taxes only US activities plus border adjustment that effectively denies a tax deduction for imported inputs and relieves export receipts from tax. Popular discussion of the proposal has focused on the last provision and dubbed it the "border adjustment tax," though border adjustment was put forward as a component of a broader proposal. Even a cash-flow tax without border adjustment would represent a major departure from the current tax system.

\footnotetext{
* This paper was originally prepared for the Brookings Panel on Economic Activity and presented at its Fall, 2017, conference. I am grateful to Dhammika Dharmapala, Bill Gale, Mick Keen, Drew Lyon, Peter Merrill, Jim Stock, John Vella, Alan Viard, and conference participants for comments on earlier drafts.

${ }^{1}$ https://abetterway.speaker.gov/_assets/pdf/ABetterWay-Tax-PolicyPaper.pdf
} 
One may also think of the DBCFT in relation to consumption taxation. Starting with the national income identity,

$$
G D P=C+I+G+X-M,
$$

it follows that taxing consumption can be achieved by taxing income net of exports, taxing imports, and allowing expensing of investment (and not taxing government purchases). Indeed, this is how value-added taxes (VATs) work in practice. In particular, VATs effectively exempt purchases of investment goods and impose border adjustment. The border adjustment is needed to tax domestic consumption, because some consumption goods are imported and some goods produced domestically are not consumed here.

If one divides private GDP (GDP - G) into returns to labor, $W$, and capital, $R$, then this tax can be implemented in two pieces, as a tax on returns to labor, $W$, plus a border-adjusted tax on business cash flows, $R-I-X+M=C-W$; this is the DBCFT. Thus, the DBCFT is equivalent to a tax on consumption net of returns to labor, or equivalently to the combination of a VAT and a wage-subsidy at an equal tax rate. The notion of separating a consumption tax into two pieces in this manner goes back to Hall and Rabushka (1983), who saw taxing wages at the individual rather than the business level as allowing progressive wage taxation (via a tax exempt threshold) based on the individual's ability to pay. However, Hall and Rabushka envisioned the cash-flow tax component as being imposed on an origin basis - i.e., without border adjustment - and early discussions of business cash-flow taxation (e.g., Institute for Fiscal Studies, 1978) likewise did not explicitly call for border adjustment. One might think that the difference between origin- and destination-based approaches relates primarily to the timing of tax collections, to the extent that the present value of a country's trade surpluses is zero, but this fails to account for potentially important differences in incentives faced by multinational businesses, as well as in short-run adjustment.

\section{Why Consider the DBCFT?}

Over the years, there has been considerable discussion of the potential benefits of a shift from taxing business income to taxing business cash flow (e.g., Auerbach, 1990), and I will offer only a brief summary here. Among the advantages are a more even tax treatment (at least at the business level) of the returns to suppliers of debt and equity capital, simplicity in not requiring the measurement of income (and, by corollary, robustness to inflation), and elimination of the tax on the normal return to investment. The last conclusion follows from the fact that, by taking the same share of investment expenses and investment returns under cash flow taxation (assuming there is symmetric treatment of gains and losses, an issue discussed further below), the government essentially becomes a silent partner in the enterprise. Thus, for any projects that are scalable, there is no change in the company's opportunity set - it can simply expand its scale to cover the government's share. However, for projects that yield above-market inframarginal returns that are not scalable, the government collects a share of these returns. Hence, the cash-flow tax acts as a tax on pure profits, exempting only the normal return from 
taxation. Finally, because adoption of a cash-flow tax provides no tax benefits for existing assets, it limits the windfalls that would be provided by a tax-rate reduction. ${ }^{2}$ All of these arguments apply to the DBCFT as well, but the focus on applying the cash-flow tax on a destination basis is of more recent vintage. This focus reflects the evolution of the corporate sector as well as the policy responses of governments around the world.

\section{A. The Changing Corporate Landscape}

If, as just suggested, the effective tax rate on corporate investment can be reduced and investment encouraged without reductions in statutory corporate tax rates, then what explains the evolution of corporate tax rates over time? Figure 1 displays the combined (federal plus subnational) statutory tax rates for the G-7 countries since 1990, and also that for Ireland, a country often in the news for its tax policy toward multinationals. While the US tax rate has changed little over this period, the general international trend has been downward, in some cases quite strongly so. As a consequence, the United States has gone from being toward the low end of the group - even lower than Ireland - to being the highest, not only among the G-7 countries but among all OECD economies. ${ }^{3}$

Figure 1. G-7 Corporate Tax Rates Since 1990

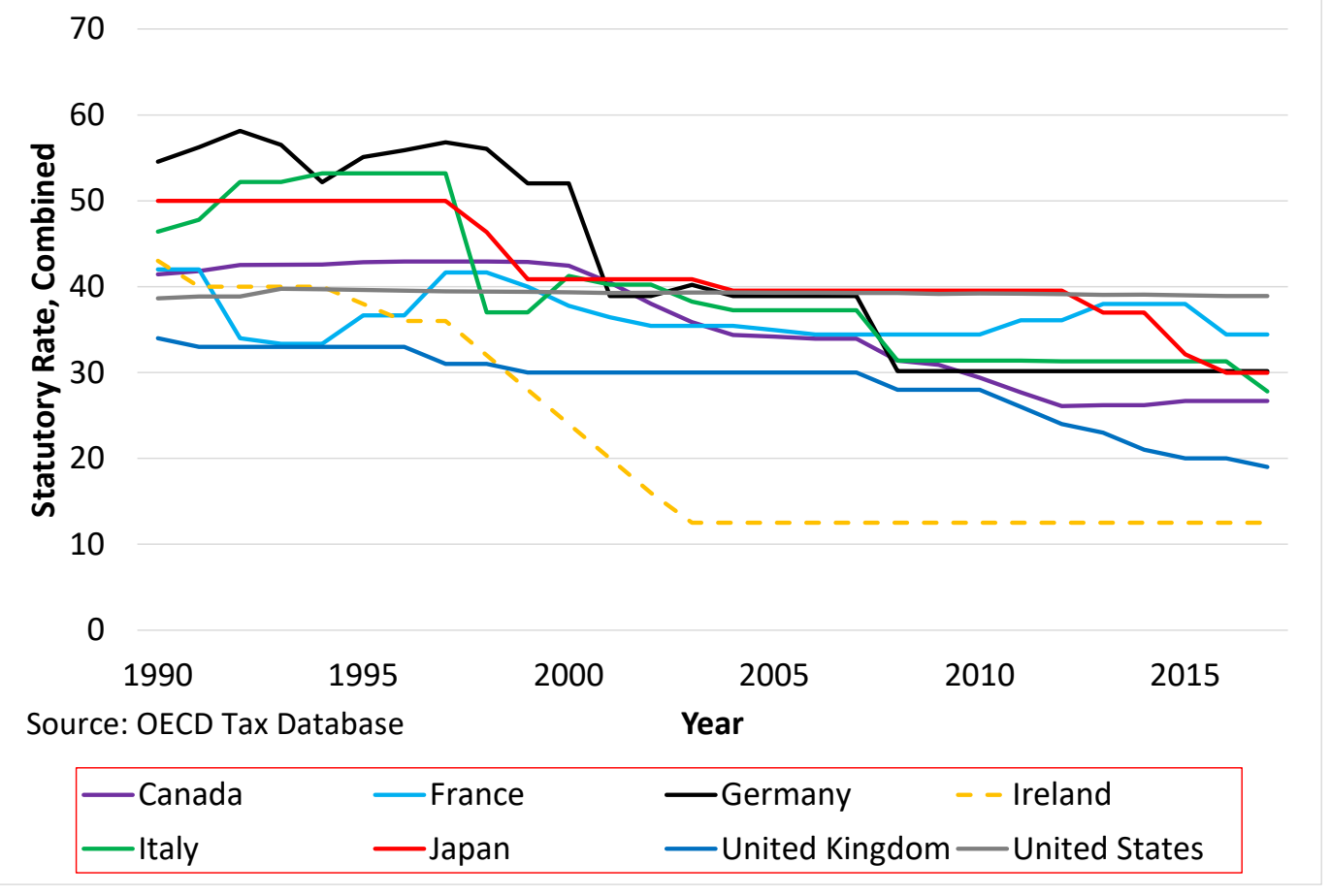

\footnotetext{
${ }^{2}$ As discussed by Auerbach and Kotlikoff (1987), one may view the distinction between expensing and rate cuts as a tax on existing wealth, in present value, which has benefits in terms of both efficiency and tax incidence.

${ }^{3}$ According to the OECD tax database (https://stats.oecd.org/index.aspx?DataSetCode=Table III), France has the next highest tax rate among all OECD countries, at nearly 4.5 percentage points below the US rate. But that is in the process of changing, according to legislation (enacted prior to the recent French presidential election) that provides for a gradual reduction of over 5 percentage points in the corporate tax rate through 2020.
} 
What is driving tax rates down? Evidence (Devereux et al., 2008) suggests competition over statutory corporate tax rates, in addition to the marginal effective tax rates facing new investment, which are also affected by investment incentives such as the expensing provided under cash-flow taxation. The motivation for competing over statutory tax rates, rather than just effective tax rates, is that behavioral responses among businesses are multidimensional. While the intensive investment decision (i.e., how much to invest in a given country given the existence of operations there) and its responsiveness to the effective tax rate have been the traditional focus of the tax policy literature (e.g., Hassett and Hubbard, 2002), the relevance of other behavioral responses that depend on the statutory tax rate, as detailed below, has grown. This shift reflects the changing nature of the business sector in the United States and elsewhere, particularly the growth of intellectual property as a source of business income, and the increasing dominance of the multinational company within the corporate sector.

As an illustration, by market capitalization, the five largest US public companies in 2016 were Apple, Alphabet, Microsoft, Exxon Mobil, and Amazon. Fifty years earlier, the top five by the same measure were AT\&T, IBM, General Motors, Exxon Mobil, and Eastman Kodak. ${ }^{4}$ There has clearly been a rise in importance of companies that rely heavily on intellectual property; it is also notable that the AT\&T that topped the list in 1966 was a mammoth regulated monopoly that provided everything from telephone services to telephones to US households and businesses. The rising importance of intellectual property for the economy as a whole is evident from aggregate statistics, which show a doubling of the share of intangible assets in the nonresidential capital stock over this same period. ${ }^{5}$ The growing importance of multinational activity (as opposed simply to exports of domestically produced goods and services) may be seen by the increasing share of the profits of US companies coming from foreign operations, which rose by almost a factor of six over this half century. ${ }^{6}$ These trends are related, of course; it is less costly to assemble and ship software or smartphones across different locations than cars or mainframe computers. With these changes have come pressures on the way most countries, and especially the United States, try to tax business income, making approaches based on corporate residence and the location of profits and production increasingly infeasible.

\section{Increased Pressure on Corporate Residence}

By continuing to impose tax on the foreign-source active business income of US companies, the United States (now alone among the G-7 countries) attempts to impose a tax on US companies

\footnotetext{
${ }^{4}$ I am grateful to Joe Sullivan for performing these calculations based on Compustat data.

${ }^{5}$ According to Table B.103 of the Federal Reserve's Financial Accounts of the United States, the share of nonfinancial corporate assets accounted for by "intellectual property products" went from 5 percent in 1966 to 10 percent in 2016. A similar doubling is present in Bureau of Economic Analysis capital stock data (Table 2.1), which finds that the share of the private nonresidential capital stock accounted for by intellectual property assets went from 6 percent to 12 percent over the same period.

${ }^{6}$ According to Table 6.17 of the National Income and Product Accounts, the fraction of before-tax corporate profits of US residents (equal to domestic profits net of payments to foreigners, plus foreign profits) coming from foreign profits rose from 6.3 percent to 35.7 percent.
} 
that is not faced by foreign companies. For example, if two companies, one US and one French, both have operations in the United States and France, the United States taxes the income of the US company in both countries while France taxes the operations of both companies only in France. Thus, the US company faces taxes in both countries on its French operations. Given that the United States provides a foreign tax credit, the extra tax is not particularly important in this example, as France's tax rate is nearly as high as that of the United States. But it matters more where the two companies also have operations in a third, low-tax country, such as Ireland, for then the additional tax on Irish income may be substantial for the US company.

This situation has given rise to two types of behavioral responses, both relating to the US statutory tax rate. First, because US tax is imposed on foreign earnings upon their repatriation, companies have an incentive to keep profits offshore, a so-called "lock-out" effect. Recent estimates by the Joint Committee on Taxation put the accumulation of untaxed offshore earnings at \$2.6 trillion. ${ }^{7}$ Second, companies that can relinquish US residency through a corporate "inversion" (so named because the earliest such transactions were accomplished through an inversion of the ordering of the US parent and an offshore subsidiary in the corporate structure) may avoid the additional layer of US taxes on their offshore earnings by taking up residence in a country that does not impose worldwide taxation. While a series of government actions (including provisions of the American Jobs Creation Act of 2004 and Treasury regulations adopted during the Obama administration) have placed various hurdles in the path of corporate inversions, they have not stopped the inversion process, which now requires merger with a sufficiently large non-US company. ${ }^{8}$

\section{Increased Pressure on the Location of Corporate Production}

As Figure 1 illustrates, companies that produce and earn income in the United States face a higher statutory tax rate than those that produce in other countries. Many skeptics about the relevance of this disparity for production decisions have noted that the US effective tax rate is below the statutory rate, because of investment incentives like bonus deprecation. But, for discrete location decisions, which may involve not only the level of investment but also the location of profitable activities (e.g., firm-specific rents, etc.), statutory tax rates may matter as well, because profits are subject to the full tax rate. Evidence confirms that location decisions depend on statutory tax rates, not just marginal effective tax rates (Devereux and Griffith, 1998). Thus, a higher US statutory tax rate encourages companies, whether domestic or foreign, to locate production activities elsewhere.

While definitive empirical evidence is lacking on the changing sensitivity of production location decisions over time, one may conjecture that the non-tax costs of relocation would be lower today, when more companies already have extensive international production networks and the added transport costs from a new location are likely to be lower.

\footnotetext{
${ }^{7}$ https://waysandmeans.house.gov/wp-content/uploads/2016/09/20160831-Barthold-Letter-to-BradyNeal.pdf

${ }^{8}$ Recent data on inversions may be found at https://www.bloomberg.com/graphics/tax-inversion-tracker/.
} 


\section{Increased Pressure on the Location of Reported Corporate Profits}

Perhaps the most salient aspect of corporate tax avoidance, at least among the general public, is the profit-shifting behavior through which companies report large profits in tax havens and other low-tax countries. ${ }^{9}$ By one recent estimate (Zucman, 2014), over half of US corporate profits reported from overseas operations were located in tax havens (including Ireland, as well as Luxembourg, the Netherlands, and Switzerland).

Although profit shifting may be accomplished through the location of tax deductible activities such as borrowing in high-tax countries, one mechanism that has received considerable attention, and indeed was an important focus of a recent, massive OECD project on "base erosion and profit shifting" (BEPS), ${ }^{10}$ is the use of artificial internal transfer prices between parts of the overall enterprise to inflate the share of overall costs incurred in high-tax countries and to inflate the share of overall revenues achieved in low tax countries. ${ }^{11}$

While manipulation of transfer pricing is a long-standing issue, the growth of intellectual property use and multinational operations enhance the challenge facing governments in attempting to determine where profits are generated among a range of possible jurisdictions through the use of unique intangible assets with no clearly identifiable physical location. And, again, the firm's incentive to engage in transfer pricing manipulation depends on a country's statutory tax rate, because it is the location of profits alone that is being altered.

There is, of course, no exact measure of the extent to which the location of profits is misreported, since this would presume an ability to measure the correct location. That would be difficult in part because it would imply that profits are located in a specific location when they are generated jointly by simultaneous production activities in different locations. However, one can construct rough estimates by comparing the reported location of profits to the location of less easily manipulated measures of activity, such as sales and payroll. Using this approach - allocating the worldwide profits of US multinationals according to a simple average of worldwide payroll shares and sales shares - Guvenen et al. (2017) estimate that these companies shifted $\$ 280$ billion in profits out of the United States in $2012 .{ }^{12}$ This overstatement of net US imports would account for more than half of that year's trade deficit.

\footnotetext{
${ }^{9}$ There is no clear distinction between a low-tax-rate country and a tax haven and there has been much litigation on the issue, as with the current dispute between the European Commission and Ireland over its taxation (or nontaxation) of Apple (http://europa.eu/rapid/press-release_IP-16-2923_en.htm). In general, one may think of a tax haven as a country that, in addition to having a low tax rate, has other practices that facilitate profit shifting.

10 http://www.oecd.org/tax/beps/

${ }^{11}$ As a simple example, a US parent company with a subsidiary in Ireland could sell assets to the Irish subsidiary at a low price and then lease the services of that asset back at a high price. There are of course rules that attempt to limit such activity, and an objective of the BEPS project was to strengthen such rules.

${ }^{12}$ Clausing (2016) arrives at estimates of a similar size using a somewhat different, regression-based methodology, also based on aggregate data. Dharmapala (2014) provides a general survey of methodology and evidence regarding worldwide profit shifting, including estimates based on firm-level behavioral responses.
} 


\section{B. The DBCFT as a Solution}

All of the problems of the current US tax system just discussed relate to the US statutory tax rate, and a simple response to address them would be a substantial reduction in the corporate tax rate, as well as the tax rate for pass-through entities (businesses not subject to the corporate tax), which now account for around half of all business income generated in the United States (DeBacker and Prisinzano, 2015). But, as a practical matter, other measures would be needed to offset the large associated revenue loss, and it is on the determination of these other measures that attempts at corporate tax reform have foundered in the recent past. Further, reactions by other countries could lead to another round of tax rate reductions and raise the need for further action.

Other reform proposals have attempted to change the structure of taxation as a way of dealing with the problems of the existing system. For example, many have called for US adoption of a territorial tax system, relinquishing its residual claim on the offshore profits of US companies. But while a shift to a territorial tax system would help address the problems associated with US residence, ${ }^{13}$ it would increase the incentives to shift offshore profits and activities - which would no longer face any residual US tax if moved abroad. Indeed, as the recent tax rates trends in Figure 1 illustrate, the two G-7 countries that most recently (in 2009) adopted territorial tax systems - the United Kingdom and Japan - show little evidence of having alleviated the need to reduce their corporate tax rates to remain competitive. An alternative would be to move closer to worldwide taxation, through adoption of a substantial minimum tax without deferral on US companies' offshore earnings. This approach would reduce incentives for US companies to shift activities and profits abroad (because offshore earnings would face higher US tax), but would increase the tax penalty on US residence and therefore increase incentives for corporate inversion. ${ }^{14}$ Combining these two approaches, marrying a territorial system with a worldwide minimum tax (as proposed by the Obama Administration in its later years), involves compromises with respect to the different objectives.

By contrast, the DBCFT forcefully confronts all of the problems discussed here, and does so in a manner that makes business decisions no longer sensitive to the US tax rate on their activities. Like a territorial tax system, it would impose no penalty on being a US resident company - the tax provisions would apply equally within the United States to foreign companies. Because transactions with related foreign entities would be ignored by the tax system (the border adjustment offsetting any US tax on receipts or deduction of expenses associated with cross-border transactions), there would be no incentive to use transfer-pricing manipulation to reduce US profits. Indeed, because profits in other countries would still be increased by such activity (assuming these countries maintained their existing tax systems

\footnotetext{
${ }^{13}$ The lock-out effect would vanish because there would be no tax on profit repatriation, and inversions would lose their appeal because US companies would no longer face an additional tax on offshore income.

${ }^{14}$ By eliminating deferred taxation of offshore profits under the minimum tax, this approach also would lessen the lock-out effect discouraging profit repatriation.
} 
based on the location of production), companies would have an incentive to shift profits toward the United States. ${ }^{15}$ Finally, because border adjustment would have the effect of imposing tax based on where products are sold, rather than on where they are produced, the DBCFT would eliminate any tax on business profits imposed as a consequence of producing in the United States. Again assuming that other countries continue to tax profits based on the location of production, this would introduce a tax differential in favor of producing in the United States.

Perhaps the simplest way to demonstrate this last point builds on the discussion of border adjustment in Auerbach (1997). Consider again the tax base of the DBCFT in terms of components of the national income identity, equal to domestic cash flow plus the trade deficit,

$$
\text { DBCFT Tax Base }=R-I-X+M
$$

According to the balance of current and capital accounts, the trade deficit equals net foreign source income less net foreign investment, $M-X=R^{f}-f$. Combining these equations yields:

$$
\text { DBCFT Tax Base }=(R-I)+\left(R^{f}-I^{f}\right)
$$

That is, the DBCFT imposes a tax on domestic as well as cross-border cash flows. Without border adjustment, the tax base is just domestic cash flow, $R-I$.

Thus, for projects with positive present-value cash flow, either because of inframarginal returns to new investment or any returns to past investment, the tax without border adjustment imposes a positive tax liability on domestic projects and discourages the location of such projects domestically. A firm could reduce its US tax liability by locating the new project (or relocating an existing project) abroad, although the net tax consequences would of course depend on foreign taxes (as well as the firm's ability to avoid US taxes by shifting profits).

By contrast, the DBCFT imposes the same US tax liability regardless of where the project is undertaken. ${ }^{16}$ If a project is undertaken with funds from the United States, it will either involve domestic investment and returns, elements of $I$ and $R$, or investment abroad and returns from abroad, equal size elements of both $f$ and $R^{f}$ assuming the same underlying project. If the project is undertaken with funds from abroad, it will either take place abroad and have no contact with the US tax system, or will occur via inbound US investment and outbound returns, generating elements of $I$ and $R$ but also cross-border cash flows of the same absolute value but opposite in sign in the expression for the DBCFT base - a positive element of If and a negative element of $R^{f} .{ }^{17}$ Combining the domestic and cross-border components, the

\footnotetext{
${ }^{15}$ See examples 9 and 10 in Auerbach and Holtz-Eakin (2016).

${ }^{16}$ While cross-border taxation applies to imports and exports, rather than directly to income and investment flows, the impact on the latter will occur through adjustments in the real exchange rate (discussed further below), which lower their real values, from a US perspective.

${ }^{17}$ For example, a $\$ 100$ investment from abroad that yields concurrent returns of $\$ 120$ will generate domestic cash flows of $\$ 20$ but a net cross-border flow of $-\$ 20$, with no impact on the DBCFT base.
} 
net US tax base will again be zero. Whatever the source of investment funds, then, there will be no incremental US tax imposed as a consequence of locating the project in the United States rather than abroad. In this sense, there will be no "made in America" tax, to adopt a slogan in recent use.

As with profit shifting, eliminating US tax consequences would not leave taxes out of location decisions, to the extent that other countries continue to tax based on the location of production. Again, the environment would be one favoring US location.

Note that all of these effects of the DBCFT hold even if the tax rate faced by businesses remains at its current level.

\section{Issues Confronting Potential Adoption of the DBCFT}

Although transition issues confront adoption of any major tax reform, some are rather specific to the DBCFT and hence worth particular attention.

\section{A. Tax Revenues}

One of the attractions of the DBCFT, as proposed in the House Blueprint, is the large revenue gain over the next several years associated with the border adjustment provision. While there is no official revenue estimate available as yet from the Joint Committee on Taxation, the Tax Policy Center (2016) estimates that the border adjustment provision would generate approximately $\$ 1.2$ trillion in tax revenue over the 10-year budget window ending in fiscal year 2026. This estimate reflects the large trade deficits forecast under current law. Leaving aside the usual difficulties involved in forecasting revenues, this estimate has been subject to two main criticisms, one involving whether estimated short-run gains will materialize and the other suggesting that any such gains will be temporary.

The first argument is that, to the extent that border adjustment reduces trade deficits, the revenue associated with border adjustment will evaporate. To focus on the revenue effects of border adjustment specifically, rather than the full reform, consider the impact of introducing border adjustment to a system that already has the remaining elements of the DBCFT, i.e., an origin-based cash-flow tax. The tax base for such a system, in terms of the components of the national income identity, is

$$
G D P_{B}-G_{B}-I_{B}=C_{B}+X_{B}-M_{B}
$$

where the subscript " $B$ " indicates values that hold before the introduction of border adjustment. After introduction of border adjustment, the tax base is:

$$
G D P_{A}-G_{A}-I_{A}-X_{A}+M_{A}=C_{A}
$$

The argument made here may be expressed simply as follows: if GDP, government purchases $(G)$ and domestic investment $(I)$ are all fixed, then the tax base rises by $M_{A}-X_{A}$, i.e., the relevant trade deficit for estimating revenue is the one that holds after the reform. Hence, if net imports are low after the reform, so will be the tax base increase. 
However, assuming that GDP does not change rules out not only actual output effects, but also any increases in measured GDP due to reduced transfer pricing manipulation. To the extent that net imports decline simply from reduced transfer pricing manipulation, there should be a one-for-one increase in measured GDP; that is, GDP $-X+M$ remains constant. In other words, such a shift should not be associated with a change in consumption, and one can compare the right-hand side of the above equations to estimate the change in the tax base, with the result being a rise in $M_{B}-X_{B}$, i.e., the trade deficit before the tax reform. Put another way, once transfer-pricing transactions have been eliminated from the tax base for multinational companies, these transactions' new levels become irrelevant to the tax base. ${ }^{18}$

The second argument, that the revenue gain from border adjustment is temporary, is based on the long-run constraint on trade deficits, which indicates that the present value of a country's future trade deficits equals the initial value of its international investment position (i.e., net assets relative to the rest of the world). This relationship would seem to imply that at some point in the future the United States, which has a negative international investment position at present, will need to begin running trade surpluses, at which time border adjustment will become a sink rather than a source of revenues. ${ }^{19}$ This argument, too, does not take into account the role that mismeasurement of trade deficits may play. To see this, note that the law of motion governing the evolution of the international investment position (IIP) is:

$$
I I P_{t}=(1+r) I I P_{t-1}+\left(r_{A}-r\right) A_{t-1}-T D_{t}
$$

where $r_{A}$ is the rate of return on the US international assets, $A, r$ is the rate of return on US international liabilities, (IIP - A), and TD is the trade deficit. If $r=r_{A}$, then this expression, along with a terminal condition on the growth of IIP, yields the standard result that IIP equals the present value of future trade deficits, $T D$, discounted at rate $r$. It has long been noted, though, that $r<r_{A}$ for the United States. Indeed, the 2016 US international investment position was $\$ 8.1$ trillion but US net investment income was $+\$ 192$ billion in the same year. ${ }^{20}$ As the equation indicates, a persistent gap between $r$ and $r_{A}$ increases the size of future trade deficits for a given evolution of the international investment position.

While much of the focus on this gap has been on the relative importance of foreign direct investment in the US foreign asset position (relative to passive investment, especially in safe, low-yield government securities, that are more prominent in the portfolios of foreign investors in US assets), one explanation for this difference is simply the transfer pricing

\footnotetext{
${ }^{18}$ The same argument holds to the extent that measured GDP changes due simply to dollar appreciation. For example, if there are no changes in consumption, investment, government purchases, or the quantities of imports and exports, and the dollar value of net exports (which are negative) and hence GDP rises due to dollar appreciation, then the change in the tax base moving from $\mathrm{B}$ to $\mathrm{A}$ will still equal $M_{B}-X_{B}$.

${ }^{19}$ See, for example, Blanchard and Furman (2017).

${ }^{20}$ The figures come from BEA International Investment Position (IIP) Table 1.1 and International Transactions (ITA) Table 1.1, respectively.
} 
manipulation already discussed. This is because shifting profits to related foreign entities not only increases measured net imports; it also increases measured returns to offshore investments, by the same amount - overstated imports generate overstated profits of foreign subsidiaries. (This is why, as discussed above, such a large share of the offshore profits of US multinationals are reported in tax havens.) Trade deficits that arise through this mechanism have no impact on the evolution of the international investment position, because they generate equal-size increases in net foreign investment income. Hence, they do not need to be offset by future trade surpluses. From the perspective of the tax base, and tax revenue, then, they represent a potentially large, permanent source, if one also takes into account the previous point that one should use the trajectory of projected trade deficits under current policy (without border adjustment) in estimating the impact on the tax base. ${ }^{21}$

\section{B. Technical Tax Design Issues}

Fleshing out a proposal for major tax reform is a considerable undertaking. Leaving aside transition issues, discussed below, a number of other issues relate to the change in tax structure under the DBCFT. Among the important issues to be resolved are the following:

\section{Net Operating Losses}

Under the existing tax system, companies with net operating losses may carry back losses to a prior year or carry losses forward (without interest) for several years to offset future tax liability. For a number of reasons, this is not a fully satisfactory approach; it blunts the effectiveness of tax benefits aimed at encouraging certain types of behavior (e.g., investment incentives) and reduces the tax system's role as an automatic stabilizer, given that losses are more prevalent in recession. But the problems could be worse under a cash-flow tax, because of the upfront receipt of deductions for investment costs (although there would be a significant offset from the loss of the interest deduction), and especially so under a DBCFT for firms with large shares of (nontaxable) exports among their sales. Patel and McClelland (2017) estimate from simulations based on corporate tax returns that net operating losses would increase as a consequence of adoption of a DBCFT. A widespread inability of exporting firms to benefit from tax relief on their imports could have important consequences in the aggregate, by undercutting the symmetry between the treatment of exports and imports and making border adjustment more closely resemble an import tariff, with the associated effects on trade.

The House Blueprint would deal with this issue by allowing firms to carry forward unused losses with interest. But this might not suffice for firms with significant export shares that might have persistent losses as a result. For such firms, some additional policy could be needed, with alternatives ranging from more generous treatment (such as refundability) of losses attributable to exports to a liberal policy toward paper transactions structured to

\footnotetext{
${ }^{21}$ A similar argument applies to the extent that the measured return on US liabilities falls short of the true return because of transfer pricing manipulation by foreign multinational investors on their inbound investment. These low returns also have offsetting contributions to the US trade deficit.
} 
effectively trade such tax losses. ${ }^{22}$ One potential approach, suggested by Auerbach et al. (2017), would allow losses to offset other taxes due from the business, notably payroll taxes.

\section{Treatment of Financial Institutions}

The traditional approach of VATs, effectively taken for nonfinancial companies under the House Blueprint, is to ignore financial transactions of nonfinancial companies in computing the tax base. ${ }^{23}$ But this leaves undetermined how to tax the value added (or, in the case of the DBCFT, business cash flow) of financial institutions. One possible approach, put forward in Auerbach (2010), would be to include all cash flows associated with financial transactions (of financial and nonfinancial companies) in the tax base, retaining the current system's tax on interest received and tax deduction for interest paid, but now also taxing amounts borrowed and allowing a deduction for amounts lent. As in the case of taxing real cash flows, taxing financial cash flows would exempt the normal return to financial investment, but it would bring the profits of financial companies, for example the interest rate spread between borrowing and lending, into the tax base. This option would have the disadvantage of requiring all companies to include financial flows in their tax calculations. Building on this approach, however, Auerbach et al. (2017) note that by netting offsetting positive and negative tax components between companies on opposite sides of financial transactions and subject to the same tax rate, one can reduce the scope of what is needed to capture the profits of financial institutions to the transactions between those institutions and domestic non-business entities. That is, it is not necessary to tax the financial cash flows of domestic financial businesses on their transactions with domestic nonfinancial businesses, since the tax base for the financial institution - interest receipts less lending, in the case of a loan - is equal and opposite the associated tax base for the nonfinancial institution - borrowing less interest payments. The same holds for any type of financial transactions (e.g., insurance contracts, derivatives, etc.).

\section{Pass-Through Entities}

To avoid exacerbating incentives for companies to change organizational form in response to inconsistencies in tax provisions, one would want major elements of the DBCFT to apply at least to large pass-through entities as well. (The House Blueprint covers all such entities). One issue to consider is the interaction of border adjustment with differences in tax rates, which under the Blueprint would be 20 percent for $C$ corporations and capped at 25 percent for passthrough entities (to reflect the double-taxation of $\mathrm{C}$ corporate income at the shareholder level). To avoid distorting trade flows between corporate and pass-through sectors, one would want to have the same rate of border adjustment for both types of entities, for example adjusting 80 percent of the top pass-through rate if the full corporate rate is border adjusted.

\footnotetext{
22 Such an approach, called "safe harbor leasing," was adopted in 1981 to permit firms to benefit from the Reagan tax reform's generous depreciation deductions, but repealed soon after, largely because of adverse public reaction to profitable companies being allowed to "buy their way" out of paying taxes. See Warren and Auerbach (1982).

${ }^{23}$ The House Blueprint would deny net interest deductions for nonfinancial companies, while still taxing positive net interest. But the typical nonfinancial company would not have net interest income.
} 


\section{World Trade Organization Concerns}

All changes in tax policy can affect the level and composition of international trade, but those that directly apply to international transactions immediately raise questions about compatibility with international agreements, most notably the rules of the World Trade Organization. In this regard, one should keep in mind that rules purportedly aimed at sustaining international trade and discouraging protectionist policies do not necessarily reflect basic economic reality.

In particular, border adjustment as part of a VAT is practiced around the world and is not a WTO violation, consistent with the fact that, as discussed above, border adjustment is part of what makes the VAT a tax on domestic consumption. Likewise, broad-based payroll taxes on domestic workers are not generally considered problematic. Yet, many trade policy analysts have suggested that the DBCFT - a policy that is equivalent to the combination of these two policies - a border-adjusted VAT plus a reduction in payroll taxes - may violate WTO rules and could be struck down if another country challenges it. ${ }^{24}$ Among concerns expressed are that (1) border adjustment may not be allowed for direct (i.e., on businesses or individuals) taxes as opposed to indirect (i.e., on products) taxes; (2) border adjustment in excess of domestic tax collected (which occurs because wage costs are deductible under the DBCFT and yet all export revenues are subject to border adjustment) represents an export subsidy; and (3) not giving suppliers of imported goods a deduction for foreign labor costs favors domestic producers over foreign ones. Accepting the possibility that an appeal to substance over form may not be enough, Grinberg (2017) offers some suggested approaches to resolving this potential conflict by altering the form of the DBCFT without altering its substance. ${ }^{25}$

\section{Economic Adjustment to the DBCFT}

Evaluation of the DBCFT among those outside of the tax policy community has focused less on its long-term benefits than on its short-run macroeconomic consequences, with respect to trade flows, exchange rates, prices, and asset values. This has been an important discussion and is still rapidly developing, as more researchers gain a greater understanding of the proposal. One relevant factor in addressing these questions is how other countries' tax and exchange rate policies would react to a US reform. A related series of questions regards the incidence of the DBCFT, how this would compare to the existing tax system, and the extent to which incidence depends on the macroeconomic adjustment path.

\section{Exchange Rates and Trade}

It is useful initially to consider the impact of border adjustment, on its own, on trade and exchange rates. In a textbook model with sufficient simplifying assumptions, there is general agreement that the introduction of symmetric border adjustment should have an offsetting

\footnotetext{
${ }^{24}$ See, for example, the discussion in Schön (2016).

${ }^{25}$ One possible approach would involve having all foreign companies selling in the United States register as domestic companies, to avoid judgment that the tax system discriminates against foreign companies. As Weisbach (2017) discusses, there is also a question of whether the DBCFT conforms to terms of current US tax treaties.
} 
impact on the US real exchange rate, so that the "fiscal devaluation" implicit in the border adjustment has no net impact on the real exchange rate or trade flows. One can cast this result in terms of the Lerner Symmetry Theorem, with the export subsidy and import tax having equal and opposite impacts on trade (Costinot and Werning, 2017). In the simplest environment, with completely flexible wages and prices, it is indeterminate whether the real exchange rate response would happen through the nominal exchange rate, via dollar appreciation, or an equiproportional rise in domestic wages and prices (or, for that matter, even a fall in the wages and prices in foreign countries). However, adding the assumption that exchange rate adjustment occurs faster, it is reasonable to envision that this would be the response channel.

In a more realistic setting, there are many potential complications to this conclusion. These include wealth effects associated with initial cross-border asset positions, effects of changes in the incentives for production location, other countries' exchange rate management, and stickiness in exchange rate adjustment and the pass-through of exchange rate changes into prices. ${ }^{26}$ A key question is how important these complications are for the magnitude and speed of adjustment, e.g., how long might a real exchange rate response be delayed, how much of this response might show up in domestic price and wage increases, and what might happen to trade flows and macroeconomic aggregates during the adjustment process.

Because the DBCFT is a new approach, we have no direct empirical evidence on past effects of adoption, and therefore must rely on more indirect inference. Based on an empirical analysis of recent experiments with fiscal devaluation, ${ }^{27}$ DeMooij and Keen (2013) find no significant effects on the trade balance for countries outside the Eurozone (where a fixed exchange rate would predict an impact on trade). Looking at historical changes in VATs between 1970 and 2015, Freund and Gagnon (2017) find approximately a full real exchange rate offset and little impact on the current account balance. But each of these studies has its limitations in our ability to draw inferences about the effects of the DBCFT. First, historical policy changes are generally smaller in magnitude. DeMooij and Keen do not consider effects on nominal exchange rates, and Freund and Gagnon study VAT changes, where one would expect (as they find) that domestic prices account for the main channel through which the real exchange rate adjusts. That is, if wages have downward stickiness, then a VAT increase would increase domestic costs and lead to upward pressure on prices. By contrast, because the DBCFT includes a deduction for wages, a nominal exchange rate adjustment would eliminate any upward pressure on domestic prices.

Another form of indirect evidence comes from model simulation, using empirically estimated parameters for the pass-through and the adjustment process. Based on this approach, Barbiero et al. (2017) find that, in the short run, the DBCFT would lead to nearly

\footnotetext{
${ }^{26}$ See Auerbach (2017a) for discussion.

${ }^{27}$ These experiments involved increases in VATs and reductions in employment taxes, which simulate the effects of border adjustment.
} 
complete nominal exchange rate adjustment, but that this adjustment would be the product of roughly offsetting declines in imports and exports, due to sluggish responses of exchange-rate pass-through and price adjustment that would discourage both imports and exports in the short run. In this scenario, the full exchange rate response would still leave the economy facing a macroeconomic shock. It should be stressed, though, in evaluating these results, that the model parameters, though based on empirical evidence, are obviously not based on evidence from adoption of the DBCFT. Incomplete pass-through and sluggish price adjustment that might represent optimal behavior of firms in an environment with small and short-lived fluctuations in costs and exchange rates might not apply in response to large, permanent changes associated with border adjustment.

This last point raises the issue of expectations about border adjustment. Given the speed of response in exchange rate markets, expectation of border adjustment should lead to immediate dollar appreciation. But the magnitude of dollar appreciation also depends on the policy being viewed as durable. Expectation of a quick reversal, as some have suggested might be more likely in the face of a WTO challenge, could lessen the exchange rate response and cause further short-run macroeconomic effects. ${ }^{28}$

An interesting question to address is how a border adjustment phase-in would influence predicted results. Such a policy would make little sense in a model with fast responses of exchanges rate and pass-through adjustment, as the exchange rate response in anticipation of future border adjustment could lead to a short-run worsening of domestic competitiveness. But the answer is less clear in more complex models, and it is quite possible that short-run economic disruptions would be reduced by a carefully phased implementation. As an alternative, or in conjunction, one might also consider changing, at least in the short run, the entities to which border adjustments are applied, shifting from US entities to their foreign trading partners, providing tax refunds to purchasers of US exports and imposing taxes on those exporting to the US. Though this is a less traditional approach to border adjustment, it would deal directly with any short-run stickiness of export and import prices in dollar terms; the border adjustment on exports would offset their higher foreign currency prices faced by purchasers of US goods abroad, and the border adjustment of imports would not be added to the dollar prices faced by US importers.

The overarching point here is that all major tax changes involve confronting a range of significant transition issues. Transition provisions represent an important component of the tax reform process, and ignoring this leads to distorted conclusions in weighing short-run transition costs against long-term benefits.

\footnotetext{
${ }^{28}$ Baumann et al. (2017), also using model simulation, find the duration of a border adjustment to be the main factor determining whether the economy experiences significant short-run macroeconomic shocks.
} 


\section{Asset Revaluations and Tax Incidence}

If border adjustment leads to a large dollar appreciation, this has significant implications for the real values of cross-border assets and liabilities. Foreign-currency denominated assets and liabilities of US individuals and firms would fall in value, and US dollar-denominated assets and liabilities of foreign individuals and firms would rise in value, as measured in home currencies. Aside from wealth effects, this could cause particular problems for foreign private and sovereign borrowers with large dollar-denominated liabilities. ${ }^{29}$ The wealth effects, in particular, have received attention because they have sometimes been perceived as an unintended and negative consequence of border adjustment.

However, it is worth keeping in mind the role that border adjustment plays in the construction of the DBCFT, or in the VAT. As noted above, border adjustment is part of what makes a VAT a tax on domestic consumption. Without border adjustment, a VAT is a tax on domestic production less investment. Relieving the tax on exports and introducing a tax on imports converts the VAT into a tax on domestic consumption, regardless of the source of the goods and services. The same logic applies to the DBCFT, with the difference that the tax is on consumption financed by sources other than wage and salary income. That is, as discussed above, a DBCFT is effectively a cash-flow tax on US-owned domestic and foreign assets. It is the imposition of the cash-flow tax on foreign assets that effectively leads to the loss in purchasing power of those assets. Indeed, the loss would occur regardless of whether the real exchange rate response happened through dollar appreciation or an increase in US wages and prices either way, the purchasing power of US-owned foreign assets would decline. From the perspective of foreign holders of US assets, the windfall produced by border adjustment serves to offset the loss in asset value that otherwise would be induced by the imposition of the domestic cash-flow tax. (If the corporate income tax is eliminated as part of the reform, the net windfall to foreigners is the same as the windfall gain they would receive from corporate tax repeal in isolation.) This offset is not exact due to a variety of complicating factors, such as the pricing of some foreign assets and liabilities in dollars and the fact that the cash-flow tax falls more on equity owners rather than uniformly on all asset holders. And, of course, transition provisions (e.g., will interest on existing liabilities still be deductible? will depreciation allowances still be permitted for previous investments?) also affect asset values; ${ }^{30}$ and shortrun effects on US wages and prices can transfer some of the burden of the DBCFT onto US workers, for example if prices rise and corresponding wage increases lag.

\footnotetext{
${ }^{29}$ Even though international debtors may borrow in dollars because of unstable home currencies, the risk posed by border adjustment could in principle be hedged using swaps against other major currencies, assuming that there is little likelihood of broader adoption of the DBCFT.

${ }^{30}$ For discussion and estimates of the effects on the values of foreign and US assets and liabilities (under the simplifying, but not entirely accurate, assumption that all assets are priced in the issuer's currency), see Viard (2017). Auerbach (2017b) estimates the lost value of US-owned net foreign assets, taking account of currency denominations.
} 
These complications notwithstanding, the DBCFT is still basically a tax on domestic consumption delivered via a cash-flow tax, and therefore one that does not tax consumption financed by wage and salary income - the consumption financed by existing wealth and abovenormal returns to future investments. Assuming that this consumption tax falls on the affected consumers, it would be a more progressive tax than a broad-based VAT that, taken by itself, taxes all consumption. As to the net effect on incidence of a switch from the existing corporate and business tax system to a DBCFT, this would also require knowledge of the incidence of the current tax system, about which there has been much dispute. To the extent that the current tax is borne by foreign investors, its elimination would add to the windfalls they receive. But to the extent that the current tax is shifted to US workers, the progressivity of the reform would likely be enhanced.

\section{Conclusions}

In late July, a joint statement issued by officials from the White House and Congress ${ }^{31}$ announced a plan to pursue a business tax reform that would not include border adjustment, but would be aimed at accomplishing the main goals of the DBCFT in promoting domestic production, bringing offshore profits back to United States, and protecting the US tax base. (Among the provisions that would be preserved from the House Blueprint are lower tax rates on small and large businesses and investment expensing.) How these objectives can possibly be accomplished in a fiscally responsible manner is, to say the least, not evident given all we know about the problem.

\section{References}

Auerbach, Alan J. 1990. "Debt, Equity, and the Taxation of Corporate Cash Flows," in J. Shoven and J. Waldfogel, eds., Debt, Taxes, and Corporate Restructuring. Washington: Brookings, 91126.

Auerbach, Alan J. 1997. "The Future of Fundamental Tax Reform," American Economic Review 87(2), May, 143-146.

Auerbach, Alan J. 2010. "A Modern Corporate Tax." The Hamilton Project/Center for American Progress, December.

Auerbach, Alan J. 2017a. "Border Adjustment and the Dollar." American Enterprise Institute Economic Perspectives, February.

Auerbach, Alan J. 2017b. "Notes on the US Wealth Effect of Border Adjustment," February 13. https://eml.berkeley.edu// auerbach/NotesontheUSWealthEffectofBorderAdjustment.pdf

\footnotetext{
${ }^{31}$ Paul Ryan, Mitch McConnell, Steven Mnuchin, Gary Cohn, Orrin Hatch, and Kevin Brady, "Joint Statement on Tax Reform," July 27, 2017.
} 
Auerbach, Alan J., Michael P. Devereux, Michael Keen, and John Vella. 2017. “Destination-Based Cash-Flow Taxation." Oxford Centre for Business Taxation Working Paper 17/01, January.

Auerbach, Alan J., and Douglas Holtz-Eakin. 2016. "The Role of Border Adjustments in International Taxation," American Action Forum, November 30.

Auerbach, Alan J., and Laurence J. Kotlikoff. 1987. Dynamic Fiscal Policy. Cambridge, UK: Cambridge University Press.

Barbiero, Omar, Emmanuel Farhi, Gita Gopinath, and Oleg Itskhoki. 2017. "The Economics of Border Adjustment Tax," June 21.

Baumann, Ursel, Alistair Dieppe, and Allan Gloe Dizioli. 2017. "Why Should the World Care? Analysis, Mechanisms and Spillovers of the Destination-Based Border Adjusted Tax." European Central Bank, May.

Blanchard, Olivier, and Jason Furman. 2017. "Who Pays for Border Adjustment? Sooner or Later, Americans Do." Peterson Institute for International Economics, March 8.

Clausing, Kimberly. 2016. "The Effect of Profit Shifting on the Corporate Tax Base in the United States and Beyond," National Tax Journal 69(4), December, 905-934.

Costinot, Arnaud, and Iván Werning. 2017. "The Lerner Symmetry Theorem: Generalizations and Qualifications," NBER Working Paper 23427, May.

DeBacker, Jason M., and Richard Prisinzano. 2015. "The Rise of Partnerships." Tax Notes $147(13)$, June $29,1563-75$.

Devereux, Michael P., and Rachel Griffith. 1998. "Taxes and the Location of Production: Evidence from a Panel of US Multinationals," Journal of Public Economics 68(3), June, 335-367.

Devereux, Michael P., Ben Lockwood, and Michela Redoano. 2008. "Do Countries Compete over Corporate Tax Rates?" Journal of Public Economics 92(5-6), June, 1210-1235.

Dharmapala, Dhammika. 2014. "What Do We Know about Base Erosion and Profit Shifting? A Review of the Empirical Literature," Fiscal Studies 35(4), December, 421-448.

Freund, Caroline, and Joseph Gagnon. 2017. “Do Border Adjusted Taxes Affect Trade or the Exchange Rate?" Peterson Institute for International Economics, April 5.

Grinberg, Itai. 2017. "The House GOP Blueprint Can Be Drafted to Comply with WTO Rules." April. https://papers.ssrn.com/sol3/papers.cfm?abstract id=2956048

Guvenen, Fatih, Raymond J. Mataloni, Jr., Dylan G. Rassier, and Kim J. Ruhl. 2017. “Offshore Profit Shifting and Domestic Productivity Measurement," NBER Working Paper 23324, April. Hall, Robert E., and Alvin Rabushka. 1983. Low Tax, Simple Tax, Flat Tax. New York: McGrawHill. 
Hassett, Kevin and R. Glenn Hubbard. 2002. "Tax Policy and Business Investment," in A. Auerbach and M. Feldstein, eds. Handbook of Public Economics 3. Amsterdam: Elsevier, 12931343.

Institute for Fiscal Studies. 1978. The Structure and Reform of Direct Taxation. London: Allen and Unwin.

Keen, Michael, and Ruud de Mooij. 2013. “'Fiscal Devaluation' and Fiscal Consolidation: The VAT in Troubled Times," in A. Alesina and F. Giavazzi, eds., Fiscal Policy after the Financial Crisis. Chicago: University of Chicago Press, 443-485.

Patel, Elena, and John McClelland. 2017. "What Would a Cash Flow Tax Look Like For U.S. Companies? Lessons from a Historical Panel." US Treasury, Office of Tax Analysis Working Paper 116, January.

Schön, Wolfgang. 2016. "Destination-Based Income Taxation and WTO Law: A Note." In: H. Jochum, P. Essers, M. Lang, N. Winkeljohann, and B. Wiman, eds., Practical Problems in European and International Tax Law - Essays in Honour of Manfred Mössner. Amsterdam: IBFD, 429-451.

Tax Policy Center. 2016. House GOP Tax Plan: Impact on Revenue 2016-2026 by Fiscal Year. September 16. http://www.taxpolicycenter.org/model-estimates/house-gop-tax-plan-sep2016/t16-0208-house-gop-tax-plan-impact-tax-revenue-2016-26

Viard, Alan D. 2017. "The Economic Effects of Border Adjustments," Tax Notes 154(8), February 20, 1029-1043.

Warren, Alvin C., and Alan J. Auerbach. 1982. "Transferability of Tax Incentives and the Fiction of Safe-Harbor Leasing," Harvard Law Review 95(8), June, 1752-1786.

Weisbach, David. 2017. "A Guide to the GOP Tax Plan - The Way to a Better Way," Columbia Journal of Tax Law 8(2), 171-228.

Zucman, Gabriel. 2014. "Taxing across Borders: Tracking Personal Wealth and Corporate Profits," Journal of Economic Perspectives 28(4), Fall, 121-148. 